\title{
A GIS based approach to neighbourhood physical environment and walking among adults in Colombo municipal council area, Sri Lanka
}

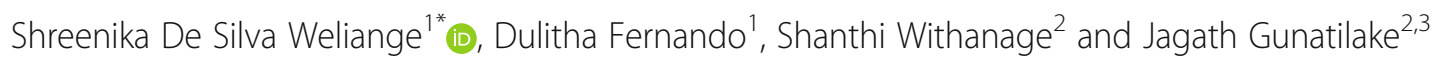

\begin{abstract}
Background: Physical Activity (PA) promotes health and wellbeing and walking is one of the easiest and commonest way to incorporate activity into everyday life. This study examined the association between the objectively measured neighbourhood physical environment and walking among the adults in Colombo Municipal Council (CMC) area in Sri Lanka.

Methods: A cross sectional study was carried out and primary data collection carried out to assess walking, sociodemographic characteristics and geo location of residence. Secondary data was obtained to assess neighbourhood environment from existing spatially referenced data from the survey department of Sri Lanka. Geographic Information Systems (GIS) was used to calculate density measures (residential density, land use, connectivity and access) and distance measures, which were then correlated with walking.

Results: A sample consisted of 284 adults aged 29-59 years with a mean age of 40.6 (SD,10.9) years. The total mean minutes walked a week was 175.8 min with a standard deviation of 214.0. The mean and the standard deviations of walking per week for transportation and leisure were 158.4 (SD,196.6) and $17.5($ SD,70.1) respectively. Residential density measures, building foot print area, length of major roads, number of intersections, number of bus stops, and distance to nearest major roads showed significant moderate degree of correlations with total minutes of walked per week, $(p<0.001)$. These results were similar with walking for transportation.

Conclusion: There is indication that neighbourhood features are associated with walking among the adults in the CMC area using secondary data on physical environment. This paves way for further exploration to understand the relationship between neighbourhood physical environment and walking which could be used for effective interventions to promote walking.
\end{abstract}

Keywords: Adults, Colombo, Geographic information systems, Neighbourhood, Physical environment, Walking

\footnotetext{
* Correspondence: shreenika@commed.cmb.ac.lk

'Department of Community Medicine, University of Colombo, Colombo, Sri Lanka

Full list of author information is available at the end of the article
}

C C The Author(s). 2021 Open Access This article is licensed under a Creative Commons Attribution 4.0 International License, which permits use, sharing, adaptation, distribution and reproduction in any medium or format, as long as you give appropriate credit to the original author(s) and the source, provide a link to the Creative Commons licence, and indicate if changes were made. The images or other third party material in this article are included in the article's Creative Commons licence, unless indicated otherwise in a credit line to the material. If material is not included in the article's Creative Commons licence and your intended use is not permitted by statutory regulation or exceeds the permitted use, you will need to obtain permission directly from the copyright holder. To view a copy of this licence, visit http://creativecommons.org/licenses/by/4.0/ The Creative Commons Public Domain Dedication waiver (http://creativecommons.org/publicdomain/zero/1.0/) applies to the data made available in this article, unless otherwise stated in a credit line to the data. 


\section{Background}

The burden of non-communicable diseases (NCDs) are on the rise in the developing countries and the mortality is reported to be $20-50 \%$ higher in Sri Lanka, than in many developed countries [1]. Among the many NCD risks, physical inactivity is the fourth leading risk factor for death in the world [2] and being inactive is known to increase the risk of cardiovascular disease, some cancers, type 2 diabetes, stroke, some mental illnesses and premature death [3-5]. In Sri Lanka, the prevalence for physical inactivity was observed to be $22.5 \%$ for males and $38.4 \%$ for females from the Non-Communicable Disease Risk Factor Survey in 2015 [6] while in district of Colombo the prevalence of inactivity was $18.0 \%$ for males and $20.3 \%$ for females [7].

Out of the many forms of physical activity, walking is one of the most common forms of activity carried out by adults. Many factors are known to influence walking, including personal and environmental factors. In describing the factors in the built environment for PA and walking, measures such as residential density, land use, intersection density, street connectivity and access and distance to facility is considered important [8]. Commonly used concepts in literature are "proximity", "connectivity" and "urban design" [9]. Proximity refers to how close different travel destinations are to one another in space and is operationalized in terms of "density" and "land use mix". Density measures the concentration of people, dwelling units or households, while land use mix refers to the spatial placement of different types of land uses (industrial, residential, commercial). When the land uses are mixed, there is greater number of destinations that are close to a person's home or office. "Connectivity" refers to the number and directness of transportation linkages between destinations [10]. A highly connected neighbourhood has many linkages between destinations and is usually defined in terms of number of road intersections in an area. A highly connected neighbourhood provides more route options for travellers and shortens trip distance, thereby influencing people to use non-motorized forms of transportation. Many environment attributes such as street connectivity, good access to destination such as to recreational facility and public transport have shown relationship with walking in the previous studies [11-17].

To assess this relationship the physical environment must be measured ether by observations of the environment through audits, perception of the environment by individuals or by using secondary data on environment. Recently with the advancement of digital maps and the Geographic Information Systems (GIS) technology, objective measures to assess the environment have been widely used in the area of PA, giving the capability to assess spatial relationships which could be useful to solve public health issues [18]. An added advantage of GIS based analysis is that that publicly available geospatial data could be a more feasible and cost-effective method for exploring relationships [19].

When using GIS to assess relationship with walking, density and distance measures should be ideally measured through network analysis. However, in situations where available data are not compatible for network analysis due to incompleteness of the network structure the recommendation is for straight line analysis [20]. The twin cities walking study environment and physical activity: GIs protocol, gives in details the common attributes that could be operationalised, also giving the concept, formulae, approach, and steps in calculating these attributes using geo referenced data [20]. Some common environmental attributes that could be assessed using GIS are population per unit area, street lights and street trees within a unit area, distance to facility, sidewalk length, building foot print area, intersections and road length per unit area etc. A GIS Based assessment of physical environment across 12 countries have been carried out assessing residential density, street connectivity, mix of land uses, and access to public transit, parks, and private recreation facilities [21] and its relationship with PA. As Sri Lanka experiences rapid urbanisation leading to changes in the built environment, it is vital that assessment of built environment and its association with walking be explored as the country progresses to achieve the targets of sustainable development goals for 2030 agenda by reducing one third of premature mortality from NCD [22]. The aim of this study was to explore the relationship between neighbourhood environment and walking among the adults in Colombo Municipal Council (CMC) area in Sri Lanka.

\section{Methods}

\section{Study aim, design and setting}

This study to explore the relationship of walking with GIS based neighbourhood environment was a subcomponent of a cross sectional study conducted in the district of Colombo with a sample of 1320 to assess the prevalence and correlates of $\mathrm{PA}$, reporting that $79.4 \%$ walked for transport and only a mere $14.5 \%$ walked for leisure [7]. The GIS analysis was carried out only in the CMC area, within the district, which is the island's economic capital, by far the country's biggest city, and the most urbanised. The aim was to report on the objectively measured physical environmental factors associated with walking using GIS. The main reason for selecting only the CMC area for GIS analysis was the availability of digital data such as the road structure, land use and other services making it possible to carry out environmental data analysis using GIS. Data collection was carried out from September 2010-February 2011. 


\section{Selection of participants}

The sample was selected using a cluster sampling method with the primary sampling unit being a Grama Niladhari Division (GND), the smallest administrative entity for which information on socio demographics are produced by Department of Census and Statistics in Sri Lanka. The GNDs selected are shown in Fig. 1. From each GND 40 households were selected. The detailed sampling mechanism has been described previously (7).

\section{Primary data collection}

Survey measures

The study instrument was a reliable and pre-tested interviewer administered questionnaire. Sociodemographics measures that were assessed were the age, sex, ethnicity, civil status, educational level, average monthly household income and self-rated health status. Walking was assessed using the validated International Physical Activity Questionnaire, Long Form (IPAQ) [23].

\section{Study Area in Colombo Municiple Council, Sri Lanka}

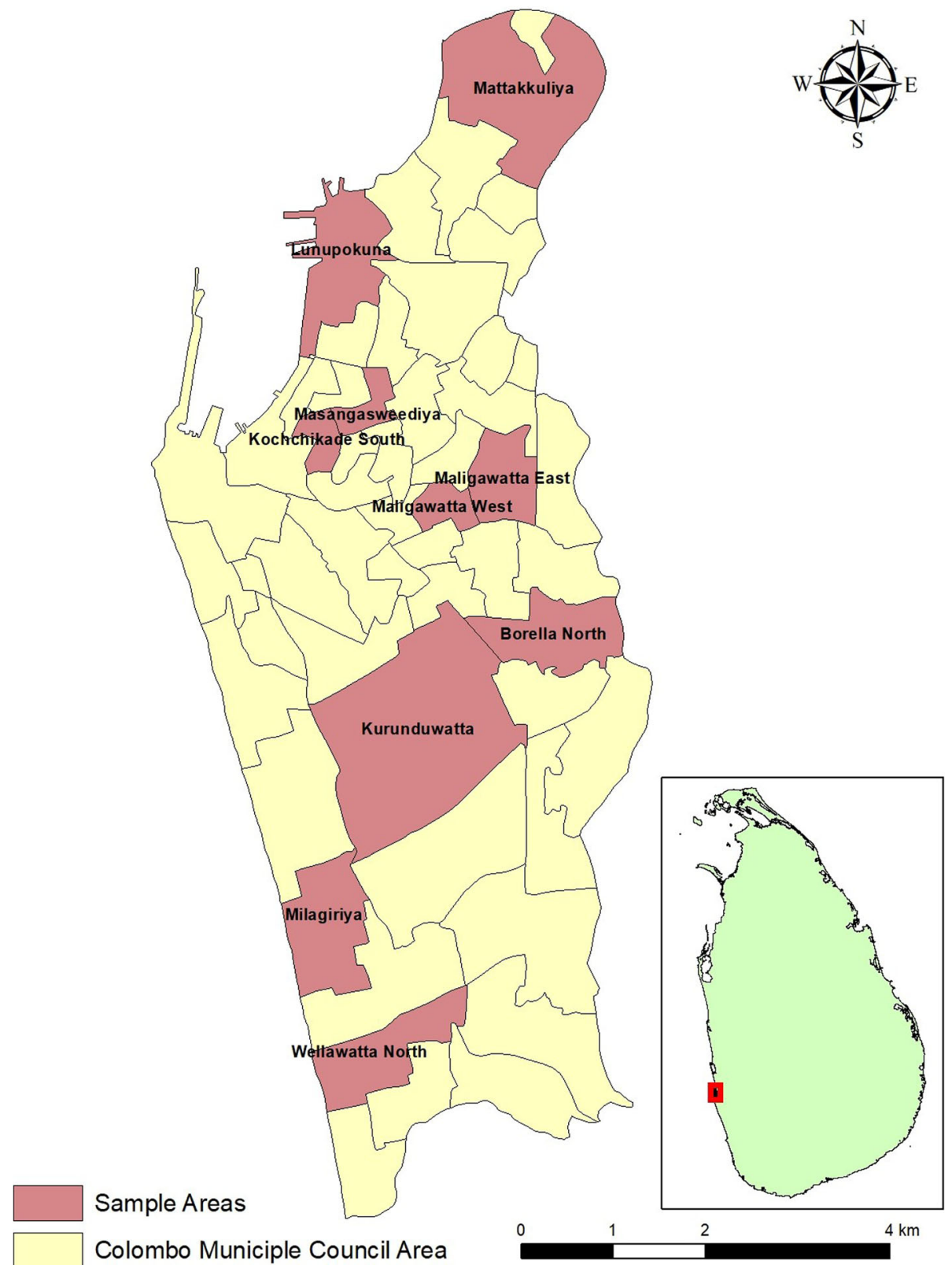

Fig. 1 CMC Neighbourhood Study map 
It is a widely used, standardized instrument to measure the habitual practice of PA of populations over the last 7 days [23-25]. Participants reported the frequency and usual duration of each type of activity including walking, undertaken during the previous week in the different domains of job, transport, domestic/garden chores and leisure. However, for this analysis only the transport and leisure related walking was selected as the neighbourhood environment features are mostly related to them $[17,21]$.

\section{Location measures}

The data collectors with a medical background were trained on measuring the coordinates of the housing location. After completing the questionnaire, the coordinates of the locations were recorded using Megallon eXplorist 510 GPS units.

\section{Secondary data collection}

Population estimates from the most recent census data in Sri Lanka was used to determine population density [26]. Neighborhood environment characteristics were obtained from the Colombo land use maps $(1: 50,000)$ which were the recent most data which were, geocoded and verified by the Survey Department, Sri Lanka. The details of the digital data layers including the scale and format are shown in Table 1. No parcel data were available.

Using the above secondary data sources the following density and distance measures were calculated.

\section{Density measures}

Density measures were carried out within the $200 \mathrm{~m}$, $400 \mathrm{~m}$ and $600 \mathrm{~m}$ buffer limit of the participant's residence. All buffers were straight-line buffers as the network structure was incomplete for Colombo. The neighbourhoods were defined by creating a $600 \mathrm{~m}$ radius "straight line" around each geo-coded participant's address. Small radii of $200 \mathrm{~m}$ and $400 \mathrm{~m}$ were also evaluated as it was hypothesised that a smaller

Table 1 Description of the digital data from the Survey Department 2010

\begin{tabular}{lll}
\hline Layer & Scale & Format \\
\hline $10 \mathrm{~m}$ Interval & $10 \mathrm{~m}$ & DGN and geo database \\
Contours & & \\
Spot Heights & $11111 \mathrm{~m}$ & DGN and geo database \\
Streams and Rivers & $1: 10,000$ & Coverage \\
Land Use & $1: 50,000$ & Coverage \\
Roads & $1: 50,000$ & Coverage \\
District, DSD, and & $1: 250,000$ and 1: 50, & Shape files and \\
GND & 000 & Coverage \\
Buildings & $1: 10,000$ & DGN format \\
\hline
\end{tabular}

area around one's home might be more influential in individual's choice to walk [18]. Population and housing density was calculated using data from the national census (26). The built area, access and connectivity density measures were calculated from the digital data from the survey department. The land use measure is a measure of ground covered with buildings, which cannot be used for walking. The number of buildings and the building foot area were then calculated within the buffer zones. Road lengths (both main and other roads) per unit area, intersections per unit area, and number of bus stops per unit area were used to assess access and connectivity.

\section{Distance measures}

Distance to the nearest major roads, nearest beach and the nearest park was calculated using the data from the survey department (Table 1) which were all were straight-line distances as network work structures were not available.

\section{Analysis \\ GIS spatial analysis}

Quality of data was verified before GIS spatial analysis. The secondary data that were collected were the most recent data. However, these were not assessed for count error (incomplete data), attribute error (inaccurate classification of facilitates or characteristics) and the positional error (inaccurate geo coding) due to logistic constraints.

The primary data collected, were rechecked for its accuracy in 10 housing locations by the experts in GPS. The coordinates of the household were downloaded from the GPS units using the vantage point software and was further visualised using the OZI explorer software. Thereafter, it was converted to shape file format as a point layer by the OZI explorer software. These were converted from their original spatial reference parameters of WGS84 to Kandawala system to be appropriate for Sri Lanka.

Initially, all the spatial data were converted in to ArcGIS geodatabase data model. Thereafter, a feature dataset was created. ArcGIS 9.3 software and its extensions such as 3D Analyst, Network Analyst, and Data interoperability were used in the study. Further, free extensions available such as Hawth's tools, X tools etc. were also used for the various spatial analysis in the study. The physical environmental variables were created and were based on the literature available, especially the GIS protocol developed for the Twin City study [20]. The concept and formulae in conducting GIS spatial analysis, for the indices are outline in Table 2. 
Table 2 Concept and formulae for the neighbourhood environment attributes

\begin{tabular}{|c|c|c|}
\hline Indices & Concept & Formulae \\
\hline \multirow{2}{*}{$\begin{array}{l}\text { Density measures for the total } \\
\text { buffer area }\end{array}$} & Population density & Number of persons within the buffer / Total buffer area \\
\hline & Housing density & Number of housing units within the buffer / Total buffer area \\
\hline \multirow{2}{*}{$\begin{array}{l}\text { Density measures for the } \\
\text { residential area }\end{array}$} & Population density & Number of persons within the buffer / Total residential buffer area \\
\hline & Housing density & $\begin{array}{l}\text { Number of housing units within the buffer / Total residential buffer } \\
\text { area }\end{array}$ \\
\hline \multirow[t]{2}{*}{ Built area measures } & Number of buildings per total buffer area & Total number of buildings per buffer area \\
\hline & $\begin{array}{l}\text { Building foot print area within the total } \\
\text { buffer area }\end{array}$ & $\begin{array}{l}\text { Building footprint area in the buffer excluding vacant or agricultural } \\
\text { land uses. }\end{array}$ \\
\hline \multirow[t]{4}{*}{ Access and connectivity } & $\begin{array}{l}\text { Length of major roads within the total } \\
\text { buffer area }\end{array}$ & $\begin{array}{l}\text { Length of major road with both interstates and ramps removed per } \\
\text { total buffer area }\end{array}$ \\
\hline & $\begin{array}{l}\text { Length of other roads within the total } \\
\text { buffer area }\end{array}$ & $\begin{array}{l}\text { Length of other road with both interstates and ramps removed per } \\
\text { total buffer area }\end{array}$ \\
\hline & $\begin{array}{l}\text { Number of intersections within the total } \\
\text { buffer area }\end{array}$ & Number of intersections within the buffer area \\
\hline & $\begin{array}{l}\text { Number of bus stops within the total } \\
\text { buffer area }\end{array}$ & Number of bus stops within the buffer area \\
\hline \multirow[t]{3}{*}{ Distance to facility } & To nearest major roads & Straight line distance to nearest major roads \\
\hline & To nearest beach & Straight line distance to nearest beach \\
\hline & To nearest park & Straight line distance to nearest park \\
\hline
\end{tabular}

\section{Analysis of walking}

Total number of minutes of walking carried out during transportation and leisure was calculated as per the IPAQ protocol $(23,24)$.

\section{Statistical analysis}

Statistical analysis was performed using SPSS version 17. The physical environmental variables created through the GIS systems for each individual was correlated with his/her minutes of walking a week. Spearman correlation coefficient was calculated as the data were not normally distributed. A threshold of 0.05 for statistical significance was used.

\section{Results}

\section{Sample characteristics}

Table 3 describes the socio-demographic characteristics of the study sample. In total, $284(71 \%)$ participants with mean age of 40.6 years $(S D=10.9)$ provided complete data after excluding participants with missing data. The sex ratio of male to females was 1: 1.3. More than half the sample had an education of above G.C.E O/L, with less than $1 \%$ having no formal education.

\section{Pattern of walking}

The pattern of walking among the study sample is shown in Table 4. The median minutes of walking for transport were $80 \mathrm{~min}$ a week (IQR 10-210). The median, and the interquartile range for the minutes walked a week for leisure was zero as only $10.5 \%$ of the persons walked for leisure. The median minutes of total walking
Table 3 Socio-demographic and perceived health of the study sample $(n=284)$

\begin{tabular}{lll}
\hline Socio- Demographic characteristic & No. & $\%$ \\
\hline Age (years) & 49 & 17.3 \\
$20-29$ & 84 & 29.6 \\
$30-39$ & 77 & 27.1 \\
$40-49$ & 74 & 26.0 \\
$50-59$ & & \\
Sex & 126 & 44 \\
Male & 158 & 56 \\
Female & & \\
Education (highest achievement) & 1 & 0.4 \\
No formal education & 30 & 10.6 \\
Grade 5 & 105 & 37.0 \\
Grade 6-grade10 & 100 & 35.2 \\
General Certificate of Education Ordinary level (G.C.E.O/L) & 33 & 11.6 \\
General Certificate of Education Advanced Level (G.C.E.A/L) & 15 & 5.2 \\
Higher education (University/diploma/technical) & & \\
Average monthly household income (in Sri Lanka Rupees) & 233 & 82.0 \\
30,000 or less & 51 & 18.0 \\
More than 30,000 & & \\
Self-rated health status & 7 & 2.5 \\
Excellent & 44 & 15.5 \\
Very good & 111 & 39.1 \\
Good & 116 & 40.8 \\
Fair & 2.1 \\
Poor & 3
\end{tabular}


Table 4 Distributions of the pattern of walking by selected socio demographic factors

\begin{tabular}{|c|c|c|c|c|c|c|c|}
\hline \multicolumn{2}{|c|}{ Characteristics } & \multicolumn{2}{|c|}{$\begin{array}{l}\text { Walking for Leisure } \\
\text { Minutes per Week } \\
\text { (IQR) }\end{array}$} & \multicolumn{2}{|c|}{$\begin{array}{l}\text { Walking for Transport Minutes per Week } \\
\text { (IQR) }\end{array}$} & \multicolumn{2}{|c|}{$\begin{array}{l}\text { Total walking- } \\
\text { Minutes per Week } \\
\text { (IQR) }\end{array}$} \\
\hline & & $\begin{array}{l}\text { Mean } \\
(\mathrm{SD})\end{array}$ & Median (IQR) & Mean (SD) & Median (IQR) & $\begin{array}{l}\text { Mean } \\
\text { (SD) }\end{array}$ & Median (IQR) \\
\hline \multirow[t]{2}{*}{ Sex } & Male $(n=126)$ & $\begin{array}{l}23.2 \\
(74.8)\end{array}$ & $\begin{array}{l}0 \\
(0-0)\end{array}$ & $\begin{array}{l}158.9 \\
(189.6)\end{array}$ & $\begin{array}{l}90 \\
(19-210)\end{array}$ & $\begin{array}{l}182.1 \\
(210.6)\end{array}$ & $\begin{array}{l}140 \\
(20-280)\end{array}$ \\
\hline & Female $(n=158)$ & $\begin{array}{l}13.0 \\
(66.2)\end{array}$ & $\begin{array}{l}0 \\
(0-0)\end{array}$ & $\begin{array}{l}157.9 \\
(202.6)\end{array}$ & $\begin{array}{l}78 \\
(0-210)\end{array}$ & $\begin{array}{l}170.9 \\
(217.2)\end{array}$ & $\begin{array}{l}90 \\
(0-218)\end{array}$ \\
\hline \multirow[t]{4}{*}{ Age Group } & $18-29(n=49)$ & $\begin{array}{l}12.8 \\
(66.5)\end{array}$ & $\begin{array}{l}0 \\
(0-0)\end{array}$ & $\begin{array}{l}161.7 \\
(179.1)\end{array}$ & $\begin{array}{l}100 \\
(0240)\end{array}$ & $\begin{array}{l}174.6 \\
(184.6)\end{array}$ & $\begin{array}{l}140 \\
(0-130)\end{array}$ \\
\hline & $30-39(n=84)$ & $\begin{array}{l}9.0 \\
(46.3)\end{array}$ & $\begin{array}{l}0 \\
(0-0)\end{array}$ & $\begin{array}{l}122.8 \\
(178.2)\end{array}$ & $\begin{array}{l}60 \\
(0-175)\end{array}$ & $\begin{array}{l}131.9 \\
(185.9)\end{array}$ & $\begin{array}{l}60 \\
(0-173)\end{array}$ \\
\hline & $40-49(n=77)$ & $\begin{array}{l}24.9 \\
(80.9)\end{array}$ & $\begin{array}{l}0 \\
(0-0)\end{array}$ & $\begin{array}{l}171.7 \\
(215.5)\end{array}$ & $\begin{array}{l}70 \\
(20-225)\end{array}$ & $\begin{array}{l}196.6 \\
(236.8)\end{array}$ & $\begin{array}{l}120 \\
(30-280)\end{array}$ \\
\hline & $50-59(n=74)$ & $\begin{array}{l}22.5 \\
(81.9)\end{array}$ & $\begin{array}{l}0 \\
(0-0)\end{array}$ & $\begin{array}{l}182.6 \\
(205.2)\end{array}$ & $\begin{array}{l}120 \\
(18-300)\end{array}$ & $\begin{array}{l}205.1 \\
(232.1)\end{array}$ & $\begin{array}{l}130 \\
(20-330)\end{array}$ \\
\hline \multirow[t]{2}{*}{ Income } & Rupees 30,000 or less $(N=233)$ & $\begin{array}{l}10.9 \\
(60.8)\end{array}$ & $\begin{array}{l}0 \\
(0-0)\end{array}$ & $\begin{array}{l}161.1 \\
(201.5)\end{array}$ & $\begin{array}{l}80 \\
(10-210)\end{array}$ & $\begin{array}{l}172.0 \\
(221.1)\end{array}$ & $\begin{array}{l}80 \\
(10-230)\end{array}$ \\
\hline & More than 30,000 Rupees $(n=51)$ & $\begin{array}{l}47.6 \\
(97.7)\end{array}$ & $\begin{array}{l}0 \\
(0-0)\end{array}$ & $\begin{array}{l}145.9 \\
(173.6)\end{array}$ & $\begin{array}{l}90 \\
(0-210)\end{array}$ & $\begin{array}{l}193.5 \\
(178.8)\end{array}$ & $\begin{array}{l}150 \\
(30-315)\end{array}$ \\
\hline Total & $N=284$ & $\begin{array}{l}17.5 \\
(70.1)\end{array}$ & $\begin{array}{l}0 \\
(0-0)\end{array}$ & $158.4(196.6)$ & $\begin{array}{l}80 \\
(10-210)\end{array}$ & $\begin{array}{l}175.8 \\
(214.0)\end{array}$ & $\begin{array}{l}105 \\
(20-270)\end{array}$ \\
\hline
\end{tabular}

among males were more than the females and more in the high-income category. Males walked more than females in total. Walking for leisure was observed more among the higher income group and among males. Walking for transport was observed more in the lower income category.

\section{Distribution of the neighbourhood environment} attributes

The physical environment attributes were assessed around $200 \mathrm{~m}, 400 \mathrm{~m}$ and $600 \mathrm{~m}$ buffers and all showed a non- normal distribution. The values for the $200 \mathrm{~m}$ buffer are shown in Table 5, as the $200 \mathrm{~m}$ is the most

Table 5 Descriptive statistics of physical environment attributes within $200 \mathrm{~m}$ buffer area $(n=284)$

\begin{tabular}{|c|c|c|c|c|c|c|}
\hline Physical environment attributes & Unit & Mean & $\begin{array}{l}\text { Standard error of } \\
\text { mean }\end{array}$ & $\begin{array}{l}\text { Standard } \\
\text { Deviation }\end{array}$ & Skewness & Kurtosis \\
\hline \multicolumn{7}{|l|}{ Density measures within a $200 \mathrm{~m}$ buffer area } \\
\hline Housing density & Houses $/ \mathrm{km}^{2}$ & 3647.8 & 119.9 & 2021.2 & 0.5 & -0.8 \\
\hline Population density & $\begin{array}{l}\text { Persons/ } \\
\mathrm{km}^{2}\end{array}$ & $20,286.2$ & 728.0 & $12,269.08$ & 0.5 & -0.9 \\
\hline \multicolumn{7}{|c|}{ Density measures per residential area within a $200 \mathrm{~m}$ buffer area } \\
\hline Housing density & Houses $/ \mathrm{km}^{2}$ & $\begin{array}{l}203 \\
563.8\end{array}$ & $175,692.3$ & $255,602.3$ & 16.8 & 282.2 \\
\hline Population density & $\begin{array}{l}\text { Persons/ } \\
\mathrm{km}^{2}\end{array}$ & $\begin{array}{l}989, \\
235.0\end{array}$ & $844,940.0$ & $142,141.7$ & 16.8 & 282.2 \\
\hline \multicolumn{7}{|l|}{ Land use measures } \\
\hline Number of buildings within the total buffer area & Units & 141.6 & 4.6 & 78.1 & 1.8 & 2.1 \\
\hline $\begin{array}{l}\text { Building foot print area within the total buffer } \\
\text { area }\end{array}$ & Units & 0.1 & 0.0 & 0.0 & 1.3 & 2.1 \\
\hline \multicolumn{7}{|l|}{ Access and connectivity } \\
\hline Length of major roads within the total buffer area & $\mathrm{m}$ & 544.9 & 26.0 & 439.6 & 0.2 & -1.1 \\
\hline Length of minor roads within the total buffer area & $\mathrm{m}$ & 2607.2 & 36.1 & 608.6 & -0.1 & -1.3 \\
\hline $\begin{array}{l}\text { Number of intersections within the total buffer } \\
\text { area }\end{array}$ & Units & 12.3 & 0.5 & 7.9 & 0.7 & -0.3 \\
\hline Number of bus stops within the total buffer area & Units & 18.5 & 0.6 & 10.4 & 0.9 & 0.11 \\
\hline
\end{tabular}


likely walked area within the neighbourhood. The mean housing densities within the residential areas was considerably higher compared to total areas depicting that there might be a large areas where non-residential buildings are present. The mean length of minor roads were more than 4 times that of the major roads showing that adequate street structure is available. It was also seen that the mean number intersections and bus stops were 12.3 and 18.5 respectively within a $200 \mathrm{~m}$ buffer area also showing that access was high in the CMC area.

\section{Association between neighbourhood physical environment and walking}

Table 6 shows that all residential density measures, number of intersections, number of bus stops, and distance to nearest major roads and beach showed positive moderate correlations with total walking, in the $200 \mathrm{~m}$ buffer zone which was statistically significant. The results were almost similar with walking for transportation with a slightly higher correlation coefficient. A negative significant correlation was observed with the building foot print area, length of major roads for the total walking. Similar correlations were observed in the $400 \mathrm{~m}$ and $600 \mathrm{~m}$ buffers. However, most environment features did not show moderate significant correlations with walking for leisure.

\section{Discussion}

Few studies have examined the relationship of the built environment and walking in developing countries through a GIS approach. This study is one of the first to examine this association in Sri Lanka. A cross sectional study methodology was adopted like many other studies looking at walking and its association with objectively measured physical environmental attributes using GIS [18]. This study adopted the GIS concepts and formulae derived from the GIS protocol developed for the Twin City Study [20] and adjusted it according to the availability of secondary data. Although, the environment data were not collected for the purpose of studies related to PA, similar approaches have been used in many other studies where the secondary data were gathered for other purposes $[27,28]$ were used for analysis as collecting environment related spatially referenced data is expensive.

It is seen from the current study that most of the walking carried out by the participants were related to transport. Only a very minimal amount of walking was

Table 6 Association between neighbourhood physical environment and walking

\begin{tabular}{|c|c|c|c|c|c|c|c|}
\hline & \multirow[t]{2}{*}{ Physical environmental attributes } & \multicolumn{2}{|c|}{$\begin{array}{l}\text { Transportation } \\
\text { walking minutes a } \\
\text { week }\end{array}$} & \multicolumn{2}{|c|}{$\begin{array}{l}\text { Leisure time } \\
\text { walking minutes a } \\
\text { week }\end{array}$} & \multicolumn{2}{|c|}{$\begin{array}{l}\text { Total walking } \\
\text { minutes a week }\end{array}$} \\
\hline & & $r$ & $p$ value & $r$ & $P$ value & $r$ & $\mathrm{p}$ value \\
\hline \multicolumn{8}{|c|}{ Density measures (at $200 \mathrm{~m}$ buffer) } \\
\hline \multirow[t]{4}{*}{ Residential Density } & Housing density per total buffer area & 0.33 & $0.001 * *$ & -0.40 & 0.499 & 0.29 & $0.001^{* *}$ \\
\hline & Population density per total buffer area & 0.33 & $0.001 * *$ & -0.03 & 0.568 & 0.29 & $0.001 * *$ \\
\hline & Housing density per residential area within buffer & 0.40 & $0.001^{* *}$ & -0.16 & $\begin{array}{l}0.01 \\
* *\end{array}$ & 0.34 & $0.001^{* *}$ \\
\hline & Population density per residential area within buffer & 0.39 & $0.001^{* *}$ & -0.17 & $0.003^{*}$ & 0.33 & $0.001^{* *}$ \\
\hline \multirow[t]{2}{*}{ Land use } & Number of buildings within the total buffer area & -0.09 & 0.12 & 0.17 & $0.004^{*}$ & -0.06 & 0.35 \\
\hline & Building foot print area within the total buffer area & 0.21 & $0.001^{* *}$ & -0.14 & $\begin{array}{l}0.02 \\
*\end{array}$ & -0.23 & $0.001^{* *}$ \\
\hline \multirow[t]{4}{*}{ Access / connectivity } & Length of major roads within the total buffer area & -0.43 & $0.001 * *$ & -0.10 & -0.09 & -0.43 & $0.001 * *$ \\
\hline & Length of minor roads within the total buffer area & -0.03 & 0.58 & -0.01 & 0.98 & -0.02 & 0.75 \\
\hline & Number of intersections within the total buffer area & 0.29 & $0.001^{* *}$ & -0.15 & $\begin{array}{l}0.02 \\
*\end{array}$ & 0.25 & $0.001 * *$ \\
\hline & Number of bus stops within the total buffer area & 0.26 & $0.001 * *$ & -0.08 & -.16 & 0.23 & $0.001^{* *}$ \\
\hline \multicolumn{8}{|c|}{ Distance measures - straight line } \\
\hline \multicolumn{2}{|c|}{ Distance to nearest major road } & 0.20 & $0.001 * *$ & 0.19 & 0.03 & 0.20 & $0.001^{* *}$ \\
\hline \multicolumn{2}{|c|}{ Distance to nearest beach } & 0.14 & $\begin{array}{l}0.02 \\
*\end{array}$ & 0.19 & $\begin{array}{l}0.01 \\
*\end{array}$ & 0.18 & $0.001^{* *}$ \\
\hline \multicolumn{2}{|c|}{ Distance to nearest grounds / park } & 0.02 & 0.77 & -0.15 & $\begin{array}{l}0.02 \\
*\end{array}$ & -0.02 & 0.74 \\
\hline
\end{tabular}

r: Spearman $r$

p: probability

**-significant at $\mathrm{p}<0.001$

*- significant at $p<0.05$ 
carried out for leisure, and that only less than 25\% walked for leisure indicated by the interquartile ranges for leisure time walking. This might be due to the fact that in Sri Lanka people do not engange routinely in physically active leisure be it walking or other forms of activity [7]. Further it is seen that males and higher income group had a higher median in total minutes of walking carried out in a week. However, when distribution of the transport related walking was considered the mean minutes of walking per week was higher in the low-income category. This might be due to the fact that lower income category commonly uses public transportation and walking to meet their transport requirement, and the higher income group might be walking for leisure which is evident from the mean scores. Similar observations are there in other studies where people in low-income households were twice as likely to walk compared to the higher income households [27]. Similarly, in China it was seen that level of total PA was higher among the low socio-economic group [29]. Both male and female respondents were less likely to engage in walking for leisure than walking for transport. However, males engaged more in walking for leisure than females. This may be due to the different roles that the males and females play in the household or due to the fact that the environment being more conducive for the male gender especially in terms of safety or social acceptance for physical activity which was seen in a qualitative inquiry carried out in Colombo, Sri Lanka [30]. The neighbourhood environment features that were operationalised for this study showed a wide variation when assessed for each as shown by the wide standard deviation, indicating the possibility that the selected neighbourhoods varied much in terms of theses environment variables. Further, the variables that were selected and operationalised were in alignment with perceived environment variables that that was selected for the scale developed and validated to assess the perceived physical and social environment associated with physical activity for Sri Lankan Adults [31].

In the present study, mild to moderate positive correlations were observed between minutes of walking for transport and total walking with residential density and connectivity at the $200 \mathrm{~m}$ buffer. This was similar to that observed in the Twin city study where the correlation coefficients ranged between $0.3-0.5$ [27]. This could be due to people engaging in more walking when there are diverse destinations and the neighbourhood is more connected. Similarly, a study done in Atlanta in 2003 [9] which assessed the net residential density (number of residential units per residential area), street connectivity (number of intersections per unit area) and land use mix (evenness of distribution of square footage of residential and commercial development) through a GIS database, showed that all of the above indicators were positively associated with the number of minutes of moderate PA per day.

The present study has limitations that should be recognized. As this study was a cross-sectional design, it prevents assessment of causality. The association of environment for leisure time walking was less concusive, possibly due to the fact that there were only few participants who engaged in waliking for leisure. Therefore, the built environment for leisure related walking needs to be further explored adopting a different methodology to compare perception of environment among those walking for leisure and those not walking for leisure. Yet, the current study generated interesting relationships between the built environment and transportation related walking. However, it is important that the findings be viewed in the backdrop of a small sample size which could have driven the possible relationships. The GIS based study had only five environmental factors and was not able to capture some important environmental variables that often are not available in GIS databases such as quality of the sidewalks, safety in the neighbourhood environment, presence of shade, traffic safe etc. which are known to be associated with walking [13-16]. However, it gives the capability to explore the walking and the environment in relation to walking using already available secondary data. The use of secondary data involved certain limitation to the analysis. Network analysis could not be carried out due to incomplete networks in the secondary data that were available. Yet, collecting primary data and carrying out objective measurement through geo-coding was not feasible due to logistic constraints in the present study as would be in many explorative studies. Therefore, this GIS study explored the possibility of using GIS based data for future studies related to PA and the physical environment in developing countries with limited resources.

This study carried many strengths, of which one is the use of a valid measurement of walking. This was assessed through a widely accepted tool, the IPAQ long form, which was also validated for the local setting previously [23] giving good validity and reliability measures. Another was making use of publicly available data for health-related research. Thirdly, this study used a similar approach is assessing the association between PA and the GIS based physical environment attributes such as residential density, land use, connectivity and used a correlation analysis $[18,27]$ enabling comparisons [28]. Further, the use of three network buffers specific to neighbourhood is a key strength of this analysis. Although the $200 \mathrm{~m}$ buffer is presented here all three buffer-specific analysis gave near comparable results. Neighbourhoods were defined around a radius of $200 \mathrm{~m}$, $400 \mathrm{~m}$ and $600 \mathrm{~m}$ from the participants residents, which 
was also the method adopted in the Twin City study [20].

\section{Conclusions}

This was the first Sri Lankan study to examine the walking and objectively measured environment attributes in adults. There is an indication that neighbourhood features are associated with walking in Sri Lankan adults. It can be concluded that GIS based studies could be adopted in Sri Lanka in understanding how neighbourhood physical environment attributes for walking are associated with the walking pattern. This understanding could help in designing effective interventions to promote walking and thereby make the people more active and healthier.

\section{Abbreviations}

CMC: Colombo Municipal Council; G.C.E.A/L: General Certificate of Education Advanced Level; G.C.E.O/L: General Certificate of Education Ordinary level GIS: Geographic Information Systems; GNDs: Grama Niladhari Divisions; GPS: Global Positioning System; IPAQ: International Physical Activity Questionnaire; IQR: Interquartile Range; NCDs: Non-Communicable Diseases; PA: Physical Activity

\section{Acknowledgements}

Authors wish to thank the administrators of the District of Colombo. The participants of the study for their support and participation. The University Grants Commission of Sri Lanka funded this research.

\section{Authors' contributions}

SDW -contributed to the design, planning the study, literature search, acquisition of data, analysis and interpretation of the results, drafting the manuscript and revising it critically and has given final approval of the version to be published. DF - contributed to the planning of the study, assisted in planning data analysis, drawing conclusions and in revising it critically for important intellectual content the preparation of the research paper and has given final approval of the version to be published. SW -contributed to data analysis, drawing conclusions and in revising it critically for important intellectual content the preparation of the research paper and has given final approval of the version to be published. JG - contributed to the planning of the study, planning data analysis, drawing conclusions and in revising it critically for important intellectual content the preparation of the research paper and has given final approval of the version to be published. All the authors have read and approved the manuscript and have given consent for publication.

\section{Funding}

The University Grants Commission of Sri Lanka funded this research (Grant No UGC/ICD/CRF2009), where funding was for primary data collection.

\section{Availability of data and materials}

The datasets used and/or analysed during the current study are available from the corresponding author on reasonable request.

\section{Declarations}

\section{Ethics approval and consent to participate}

The Ethics Review Committee of Faculty of Medicine, University of Colombo approved the study protocol (reference number EC-09-084) and data collection was carried out after obtaining informed written consent from each participant.

\section{Consent for publication}

Not applicable as no individual personal data in any form is presented here.

\section{Competing interests}

The authors declare that they have no competing interests.

\section{Author details}

Department of Community Medicine, University of Colombo, Colombo, Sri Lanka. ${ }^{2}$ Postgraduate Institute of Science, University of Peradeniya, Peradeniya, Sri Lanka. ${ }^{3}$ Department of Geology, University of Peradeniya, Peradeniya, Sri Lanka.

Received: 12 June 2020 Accepted: 5 May 2021

Published online: 26 May 2021

\section{References}

1. World Bank. Sri Lanka- addressing needs of an aging population. [On line] Available at:http://www.siteresources.worldbank.org/INTSRILANKA/ Resources/LKAgingFullRep.pdf.2008; Retrieved 20th September 2020.

2. WHO. Physical activity, available from http://www.who.int/topics/physical_a ctivity/en/, 2016; accessed on 2020/9/7.

3. Bouchard C, Shepard R, Stephens TE. Physical activity, fitness and health: International proceedings and consensus statement. Champaign: Human Kinetics; 1994

4. U.S. Department of Health and Human Services. Physical activity and health: a report of the Surgeon General. Atlanta GA, National Centers for Chronic Disease Prevention and Health Promotion, Centers for Disease Control and Prevention. 1996

5. World Health Organization. Reducing risks, promoting healthy life. The World Health Report 2002. Geneva: World Health Organization; 2002.

6. Ministry of Health 2015. Non communicable disease risk factor survey 2015. Available at: https://www.who.int/ncds/surveillance/steps/STEPS-report-201 5-Sri-Lanka.pdf. Retrieved 15 September 2020

7. De Silva Weliange S, Fernando D, Gunatilake J. Pattern of physical activity among Sri Lankan adults in the district of Colombo. Asia Pac J Public Health. 2016;28(8):725-36. https://doi.org/10.1177/1010539516660191.

8. Croucher KL, Wallace A, Duffy SY. The Influence of Land Use Mix, Density and Urban Design on Health: A Critical Literature Review. / Centre for Housing Policy, University of York; 2012. p. 54.

9. Frank $L$, Engelke $P$, Schmid T. Health and community design: the impact of the built environment on physical activity. Island Press; 2003.

10. Handy S, Boarnet M, Ewing R, Killingsworth R. How the built environment affects physical activity. Am J Prev Med. 2002;23(2):64-73. https://doi.org/1 0.1016/S0749-3797(02)00475-0

11. Bauman A, Ma G, Cuevas F, Omar Z, Waqanivalu T, Phongsavan $P$, et al. Cross-national comparisons of socioeconomic differences in the prevalence of leisure-time and occupational physical activity, and active commuting in six Asia-Pacific countries. J Epidemiol Community Health. 2010;65(1):35-43. https://doi.org/10.1136/jech.2008.086710.

12. Ogilvie D, Egan M, Hamilton V, Petticrew M. Promoting walking and cycling as an alternative to using cars: systematic review. Br Med J. 2004;329(7469): 763. https://doi.org/10.1136/bmj.38216.714560.55.

13. Sallis F, Bowles R, Bauman A, Ainsworth E, Bull C, Craig L, et al. Neighborhood environments and physical activity among adults in 11 countries. Am J Prev Med. 2009;36(6):484-90. https://doi.org/10.1016/j.a mepre.2009.01.031.

14. Wang Y, Chau C, Ng W, Leung T. A review on the effects of physical built environment attributes on enhancing walking and cycling activity levels within residential neighborhoods. Cities. 2016;50:1-15. https://doi.org/10.101 6/j.cities.2015.08.004

15. Sallis J, Cerin E, Conway T, Adams M, Frank L, Pratt M, et al. Physical activity in relation to urban environments in 14 cities worldwide: a cross-sectional study. Lancet. 2016;387(10034):2207-17. https://doi.org/10.1016/S0140-673 6(15)01284-2

16. Owen N, Humpel N, Leslie E, Bauman A, Sallis J. Understanding environmental influences on walking. Am J Prev Med. 2004;27(1):67-76. https://doi.org/10.1016/j.amepre.2004.03.006.

17. Saelens B, Handy S. Built environment correlates of walking. Med Sci Sports Exerc. 2008;40(S):S550-66. https://doi.org/10.1249/MSS.0b013e31817c67a4.

18. Fradelos E, Papathanasiou I, Mitsi D, Tsaras K, Kleisiaris C, Kourkouta L. Health based geographic information systems (GIS) and their applications. Acta Informatica Medica. 2014;22(6):402-5. https://doi.org/10.5455/aim.2014.22.4 02-405

19. McGinn P, Evenson R, Herring H, Huston L, Rodriguez A. Exploring Associations between Physical Activity and Perceived and Objective Measures of the Built Environment. J Urban Health. 2007:84(2). https://doi. org/10.1007/s11524-006-9136-4 
20. Forsyth A. Twin Cities Walking Study Environment and Physical Activity: GIS Protocols Version 4.1, 2007 Available at: http://designforhealth.net/wpcontent/uploads/2012/12/MinnGIS_Ver4_1_FINAL.pdf. Acccessed on 12.09.2 020

21. Adams M, Frank L, Schipperijn J, Smith G, Chapman J, Christiansen L, et al. International variation in neighborhood walkability, transit, and recreation environments using geographic information systems: the IPEN adult study. Int J Health Geography. 2014;13:43. https://doi.org/10.1186/1476-072X-13-43.

22. NCD Countdown 2030 collaborators. NCD Countdown 2030: pathways to achieving Sustainable Development Goal target 3.4. Health Policy. 2020; 396(10255):918-34. https://doi.org/10.1016/S0140-6736(20)31761-X.

23. Karunapema RP. Evaluation of the effectiveness of a lifestyle intervention in primary prevention of diabetes among adults with impaired fasting glucose from a rural area in Gampaha District. Sri Lanka: University of Colombo; 2007. Available at: http://archive.cmb.ac.lk/research/handle/70130/1038

24. International Physical Activity Questionnaires (IPAQ) | AHRQ Health Care Innovations Exchange. 2005. [https://innovations.ahrq.gov/qualitytools/ international-physical-activity-questionnaires-ipaq]. Accessed 17 Sept 2013.

25. Hagströmer M, Oja P, Sjöström M. The international physical activity questionnaire (IPAQ): a study of concurrent and construct validity. Public Health Nutr. 2006;9(6):755-62. https://doi.org/10.1079/PHN2005898.

26. Department of Census and Statistics. http://www.statistics.gov.lk/. 2010; Accessed 20 July 2013

27. Forsyth A, Oakes J, Schmitz K, Hearst M. Does residential density increase walking and other physical activity? Urban Stud. 2007;44(4):679-97. https:// doi.org/10.1080/00420980601184729.

28. Forsyth A, Hearst M, Oakes J, Schmitz K. Design and destinations. Factors influencing walking and Total physical activity. Urban Stud. 2008:45(9):197396. https://doi.org/10.1177/0042098008093386.

29. Shi Z, Lien N, Kumar B, Holmboe-Ottesen G. Physical activity and associated socio-demographic factors among school adolescents in Jiangsu Province, China. Prev Med. 2006;43(3):218-21. https://doi.org/10.1016/j.ypmed.2006.04 017

30. De Silva Weliange S, Fernando D, Gunatilake J. Neighbourhood social environment on physical activity among adults in Sri Lanka: a qualitative inquiry. J Col Commun Phys Sri Lanka. 2018;24(1):28-35. https://doi.org/10.4 038/jccpsl.v24i1.8164.

31. De Silva Weliange SH, Fernando D, Gunatilake J. Development and validation of a tool to assess the physical and social environment associated with physical activity among adults in Sri Lanka. BMC Public Health. 2014; 14(1):423. https://doi.org/10.1186/1471-2458-14-423.

\section{Publisher's Note}

Springer Nature remains neutral with regard to jurisdictional claims in published maps and institutional affiliations.

Ready to submit your research? Choose BMC and benefit from:

- fast, convenient online submission

- thorough peer review by experienced researchers in your field

- rapid publication on acceptance

- support for research data, including large and complex data types

- gold Open Access which fosters wider collaboration and increased citations

- maximum visibility for your research: over $100 \mathrm{M}$ website views per year

At $\mathrm{BMC}$, research is always in progress.

Learn more biomedcentral.com/submissions 